\title{
Ellison's Rinehart and Count Basie's: Invisible Man and 'Harvard Blues'
}

Brooke Conti

Cleveland State University, b.conti@csuohio.edu

Follow this and additional works at: https://engagedscholarship.csuohio.edu/cleng_facpub

Part of the Literature in English, North America Commons

How does access to this work benefit you? Let us know!

\section{Publisher's Statement}

This is a pre-copyedited, author-produced PDF of an article accepted for publication in Notes \& Queries following peer review. The version of record "Ellison's Rinehart and Count Basie's: Invisible Man and 'Harvard Blues."' Notes \& Queries 54:2 (2007), 181-83 is available online at: http://nq.oxfordjournals.org/content/54/2/181.extract

\section{Recommended Citation}

Conti, Brooke, "Ellison's Rinehart and Count Basie's: Invisible Man and 'Harvard Blues"' (2007). English Faculty Publications. 76.

https://engagedscholarship.csuohio.edu/cleng_facpub/76

This Article is brought to you for free and open access by the English Department at EngagedScholarship@CSU. It has been accepted for inclusion in English Faculty Publications by an authorized administrator of EngagedScholarship@CSU. For more information, please contact library.es@csuohio.edu. 


\section{ELLISON'S RINEHART AND COUNT BASIE'S: INVISIBLE MAN AND 'HARVARD BLUES'}

ONE of the most enigmatic characters in Ralph Ellison's Invisible Man is B. P. Rinehart-if a personage who never actually appears in the course of the novel can be considered a character. Although Ellison's unnamed narrator never meets Rinehart, in the novel's twentythird chapter he is repeatedly mistaken for this man who seems to be, simultaneously, a flashy numbers runner, hoodlum, and ladies man, but also a minister of 'the ole time religion' whose passionate preaching commands the devotion of his aged congregants. ${ }^{1}$ The narrator is amazed and initially envious of Rinehart's apparent ability to be everywhere and nowhere, shifting shape as the occasion demands. He puns on Rinehart's name - he is a man of both rind and heart - and in one of Ellison's later essays the author reveals that the man's first two initials stand for Bliss Proteus, names that further underscore the character's fluid and flexible nature. ${ }^{2}$ Despite the importance of Rinehart to the narrative, surprisingly little has been written about him, and scholarship has largely overlooked what appears to be the inspiration for both Rinehart's name and his most important characteristic: the fact that he is a fraud who is never seen.

In a 1955 interview with the Paris Review, Ellison claimed that the name Rinehart originated with a song sung by his old friend Jimmy

\footnotetext{
1 Ralph Ellison, Invisible Man (1952; reprint, New York, 2005), 497.

${ }^{2}$ Ralph Ellison, 'Change the joke and slip the yoke', Shadow and Act (New York, 1964), 56.
}

The name Rinehart haunted him, Ellison says, and its 'suggestion of inner and outer' seemed appropriate for a character who was 'a master of disguise. ${ }^{4}$ While this brief account is intriguing, it is also incomplete, and it gives no hint of the deeper and more interesting connections between the character of Rinehart and the song that I believe to be George Frazier's 'Harvard Blues', written for Rushing and the Count Basie Orchestra.

Although Ellison does not name the song that he quotes from and the lines he provides are not to be found among either the three verses of 'Harvard Blues' that Basie and Rushing recorded (first in 1941 and then in 1946) or the additional verses that Frazier penned, I believe that they probably reflect an alternate or ad-libbed verse that Rushing may have sung in live performances; it seems improbable that there could have been a second song in the Basie repertoire that, like 'Harvard Blues', is also set in Boston and involves a fellow named Rinehart. ${ }^{5}$

Here are the verses of 'Harvard Blues' that Basie and Rushing did record:

\footnotetext{
I wear Brooks clothes and white shoes all the time I wear Brooks clothes and white shoes all the time Get three 'Cs', a 'D' and think checks from home sublime

I don't keep no dogs or women in my room I don't keep no dogs or women in my room But I'll love my Vincent Baby, until the day of doom
}

\footnotetext{
3 Ralph Ellison, interview by Alfred Chester and Vilma Howard, 'The art of fiction', Paris Review, (Spring 1955). Republished in Shadow and Act, 181. The only scholar I am aware of who has even mentioned the connection between Ellison's Rinehart and a Rushing blues song is Robert G. O'Meally, who simply repeats the account that Ellison gives in this interview. See The Craft of Ralph Ellison (Cambridge, 1980), 90 .

4 Ellison, 'Art of fiction', 181.

${ }^{5}$ It is also possible that Ellison misremembered the lines in question or that, in his interview, he was inadvertently conflating two different songs, but these possibilities seem to me less likely.
} 
Rinehart, Rinehart, I'm a most indiff'rent guy Rinehart, Rinehart, I'm a most indiff'rent guy But I love my Vincent Baby, and that's no Harvard lie ${ }^{6}$

These lyrics, which are surely among the more unlikely to be sung by Rushing, focus on an undergraduate content with his gentleman's Cs (or Ds) and more concerned with his Brooks Brothers wardrobe and his society girlfriend, who belongs to Boston's Vincent Club. Nevertheless, he finds time to abide by the university's prohibition on keeping dogs or women in one's room. ${ }^{7}$ The repeated name 'Rinehart' refers to an event in Harvard lore. Harvard Magazine quotes the liner notes from a university-sponsored reissue of the 1941 recording, which explains: "Rinehart" is a Harvard rallying cry that goes back to the turn of the century. Its eponym was one James B. G. Rinehart '00, who was often hailed by a classmate beneath his window. On a warm June night in 1900, the classmate's cry of "Oh, R-i-i-i-n-e-HART!' was spontaneously taken up by hundreds of inmates of the Harvard Yard,' and the cry remained a campus rally call and inside joke for decades. ${ }^{8}$

Although this story is interesting, the real relevance of 'Harvard Blues' to Invisible Man lies not in the song's lyrics, or even the facts of the historical Rinehart's life, insofar as they can be determined. Rather, it is the story that the song's author, George Frazier, apparently spun for Basie before he had even conceived of the song. Frazier, a Harvard graduate and an influential jazz journalist, was on good terms

${ }^{6}$ George Frazier (lyrics) and William 'Count' Basie and Tab Smith (music), 'Harvard Blues', 1941. As quoted in Charles Fountain, Another Man's Poison: The Life and Writings of Columnist George Frazier (Chester, CT, 1984), 65 . The remaining verses are as follow:

Institute and Porky are my clubs Institute and Porky are my clubs And I think that girls at Radcliffe are all dubs

Went to Groton and got a big broad A Went to Groton and got a big broad $\mathrm{A}$ Now at Harvard and follow an indiff'rent way

Do my drinking down in the cool Ritz Bar Do my drinking down in the cool Ritz Bar Dad is Racquet and Chilton is my ma

${ }^{7}$ Primus V [pseud.], 'The College Pump: "I Love My Vincent Baby ...", Harvard Magazine (September-October 2002), 88 .

${ }^{8}$ Ibid. with Basie and often spent time with him and the band when they were in the same city. According to Frazier's biographer, he and Basie were together one night after a show, when Frazier

started to tell him about the Harvard Rinehart legend. Every other November, on the eve or the morning of the HarvardYale game, part of the atmosphere in the lobby of the Taft Hotel in New Haven was the faithful and incessant paging of Mr. Rinehart - 'Call for Mr. Rinehart! Call for Mr. Rinehart!'-with never a Mr. Rinehart to answer. The version of the Rinehart story told most often had it that Rinehart was a friendless young Harvard [student] who tried to present the illusion that he was in truth a popular sort by standing under his dormitory window and hailing himself. George told this and some other variations on it, and branched out on other Harvard lore as well. Basie was thoroughly amused and George came away thinking he had the makings of a song here.

With music composed by Basie and Tab Smith, and Rushing singing the vocals, the song apparently 'enjoyed a moderate success, especially on college campuses; it was a regular part of Basie's college show.' ${ }^{10}$

The connections between the Rinehart of Frazier's tale and the Rinehart of Ellison's novel should be apparent: not only do they share the same name (even spelled the same way), but both men remain unseen by their audience while nevertheless making their presence felt and both engage in elaborate subterfuge. ${ }^{11}$ The novel even contains what I would argue is a direct allusion to the song's lyrics: after the narrator has been mistaken for Rinehart for the second time and has nearly gotten into a barroom brawl as a result, he asks himself, 'Rinehart, Rinehart... what kind of man is Rinehart? ${ }^{12}$ These words

\footnotetext{
9 Fountain, 64.

10 Ibid., 65.

11 Interestingly, although Frazier himself later adopted the bearing and persona of just the kind of Harvard student that he writes about, when he was an undergraduate he was a scholarship student who never quite fit in socially. Fountain, 20.

${ }^{12}$ Ellison, Invisible Man, 490.
} 
read like an echo of the third verse of 'Harvard Blues'-and if so, the answer to the question would have to be: 'he's a most indiff' rent guy'.

Although it is impossible to be certain that Ellison knew the story that Frazier told Basie, it seems likely, and not merely because of the echoes between Ellison's Rinehart and Frazier's. While there is no record of Ellison's knowing Frazier, Ellison and Rushing were life-long friends, dating back to their childhood in Oklahoma City. ${ }^{13}$ Ellison was also on speaking terms with Basie and he was a frequent presence in New York's uptown jazz clubs. Moreover, in his interview with the Paris Review, Ellison indicates that someone did tell him something about the Harvard Rinehart legend: after he had created Rinehart, Ellison says, he learned that the name "was a call used by Harvard students when they prepared to riot, a call to chaos. Which is very interesting, because it is not long after Rinehart appears in my novel that the riot breaks out in Harlem.' ${ }^{14}$ Although Ellison claims that he heard this story only later, and he misstates the nature of the 'Rinehart' rally cry (an inaccuracy that could have originated with Frazier or Rushing), by 1955 Ellison's memory may have been fuzzy about the details of Frazier's story or its influence on his own composition process; alternately, Ellison may not have wished to reveal his character's indebtedness to someone else, or he may simply have felt that a fuller version of the story was not worth rehearsing in this particular interview.

Whatever the reason may have been, Ellison's account of the origins of his character is not particularly illuminating, and it certainly does not hint at the importance of 'Harvard Blues' and the Rinehart legend for his novel. While in the interview Ellison focuses on the revolutionary potential unleashed by Rinehart, the novel itself, as I have discussed, portrays a man much more in keeping with Frazier's Rinehart: not a revolutionary, but a trickster, an improviser, and ultimately-like the

\footnotetext{
13 Rushing was 11 years older than Ellison, but as an adolescent he was employed by Ellison's father for odd jobs. After Ellison moved to New York, he and Rushing would often get together and spend hours catching up. See Lawrence Jackson, Ralph Ellison: Emergence of Genius (New York, 2002), 19, 77; O'Meally, 28.

14 Ellison, 'Art of fiction', 181.
}

Invisible Man himself - an outsider trying to become an insider.

The fact that Frazier and Basie's Rinehart was embedded in a blues song also seems important, for the novel's Rinehart has a protean elusiveness consistent with Ellison's description of jazz and the blues. In an essay on another Oklahoma City performer, Charlie Christian, Ellison provides this description of jazz and the jazz performer that might, with only some slight alterations, describe the high-wire act that B. P. Rinehart performs:

true jazz is an art of individual assertion within and against the group. Each true jazz moment...springs from a contest in which each artist challenges all the rest; each solo flight, or improvisation, represents ... a definition of his identity as individual, as member of the collectivity and as a link in the chain of tradition. Thus, because jazz finds its very life in an endless improvisation upon traditional materials, the jazzman must lose his identity even as he finds it. ${ }^{15}$

Ellison, or at any rate his narrator, winds up rejecting 'Rinehartism' in the search for a less cynical and more authentic way of expressing his humanity and individuality, but it is difficult to feel that some admiration for Rinehart's fluidity and flexibility does not remain.

BROOKe CONTI

State University of New York at Brockport

\footnotetext{
15 Ralph Ellison, 'The Charlie Christian story', Shadow and Act, 234.
} 